\title{
Histopathological and Biochemical Evaluation of the Pulmonary Toxicity of Cadmium Chloride and thiocarbamate
}

\author{
Somaya Y.M Hamoudah, Samia I. El Naggar* and Haleem H.H.** \\ Department of Forensic Medicine and Toxicology, Faculty of Medicine (for Girls) Al \\ AL Azhar University and Department of Pathology, Cairo University* and \\ Department of Biochemistry, Animal Health Research Institute Dokki**
}

\begin{abstract}
:
The aim of the present work is to study the acute pulmonary toxicity of cadmium chloride $\left(\mathrm{CdCl}_{2}\right)$ and diethyldithiocarbamate (DDTC) each separately and in combination. A dose of $40 \mathrm{ug} / \mathrm{kg}\left(\mathrm{CdCl}_{2}\right)$ and $4 \mathrm{mg} / \mathrm{kg}$ (DDTC) were given by a single intratracheal instillation to albino rats. After 3, 7, 21 days of this single exposure, the cadmium content in the blood and lung were measured by atomic absorption spectrophotometer. It was found that the blood cadmium concentration significantly increased $(\mathrm{P}<0.001)$ with increasing the time in all treated groups.

However, with combined treatment the cadmium level in the lung showed significant decrease $(\mathrm{P}<0.001)$ after 3 days of exposure, followed by significant increase after 7 days and significant decrease again after 21 days.

Histopathological examination of the lung showed inflammatory infiltrate of alveolar septa specially around blood vessels in DDTC treated animals. While that were exposed to $\mathrm{CdCl}_{2}$ and to combined $\left(\mathrm{CdCl}_{2}+\right.$ DDTC) showed interstitial fibrosis and chronic inflammation. These changes were more severe and serious with combined exposure. Moreover the electron microscopic examination of lung tissues, after 21 days of combined exposure showed damage of type I pneumocytes, hyperplasia of type II pneumocytes with loss of microvilli. While the interstitial tissue revealed collagen bundle and chronic inflammatory cells.
\end{abstract}

\section{Introduction:}

Cadmium is an environmental pollutant (Liu et al., 1999) and is toxic to a number of organs (Habeebu et al., 2000). Cadmium and its salts are widely used in numerous industrial processes and it is a component of many commercial products. Electroplating is the major use of pure metal (Gossel and Bricker, 1994). It is reported by Williams and Halsted (1982) that cadmium is found in nature in close association with lead and zinc. During mining of these metals, they may be

released into the environment. A large number of workers are potentially exposed to cadmium during mining and processing. Keshava et al., (2000) found that cadmium chloride is capable of inducing morphological cell transformation and that transformed cells are potentially tumorigenic in the exposed workers.

The toxicological effect of cadmium was studied by many scientists. Martin et al., (2001) reported that cadmium chloride is an 
environmental toxin that might be implicated in human prostate carcinogenesis. While karmaker et al., (1999) suggested that the effect of cadmium on the liver and kidney could be correlated with a decreased level of reduced glutathione and glutathion $\mathrm{S}$ transferase activity (enzymes that contain sulfhydryl group). However, Bell et al., (1997) found that cadmium increased prostaglandin $\left(\mathrm{PGE}_{2}\right)$ in Guina pig lung when injected intratracheally. The adverse effects of cadmium on the heart function also studied by Wang et al., (1999). Genotoxic effect of cadmium chloride was studied by Fogu et al., (2000).

Furthermore Hovland et al., (1999) reported that when cadmium adminstered to mice during gestation it induced malformation of the neural tube, craniofacial region, limbs, trunk, viscera and axial skeleton.

Pollution and industrial practice result in concentrations of metal and other environmental agents that are related to environmental toxicity (Novelli et al., 1998). Dithiocarbamates are chemicals widely used in the form of pesticides, therapeutic and chelating agents (in immunotherapy for alcoholism and for heavy metal poisoning) and as scavangers. Their worldwide consumption is between 25,000 and 35,000 metric tones per annum with a growing trend (WHO, 1988).

The carbamate insecticides are reversible cholinesterase inhibitors. The mechanism of carbamate toxicity is via carbamaylation of acetyl choline esterase which resulted in accumulation of acetyl choline at muscarinic and nicotinic sites (Gossel and Bricker, 1994).

It is reported by Tinkler et al., (1998) that potential health hazards associated with dithiocarbamate include genotoxicity and possible carcino genicity. The carbamates also tend to form chelates with metals (cadmium, lead, copper etc.) with resultant change in toxicity (Gale et al., 1983).

Allergic diseases, atopy, bronchial and chronic obstructive bronchitis are diseases which can directly or indirectly be traced to changes in the function of immune system. Epidemiological studies have shown that these allergic diseases have increased in the course of time and that the incidence of obstruction of respiratory system is clearly higher in polluted region than in comparable control areas (Marth et al., 2000).

Because dithiocarbamate and cadmium can be present simultaneously in our environment, and the lung is a target organ that constantly undergoes multiple insults from air pollutants, the aim of this work is to study the pulmonary toxicity of dithiocarbamate and cadmium chloride each separately and in combination through biochemical and histopathological studies.

\section{Material and Methods:}

\section{Chemicals:}

Cadmium chloride $\left(\mathrm{CdCl}_{2}\right)$ and sodium diethyldithiocarbamate (DDTC) were obtained from Arabic Laboratory Equipment Co.

\section{Animals and Treatment:}

72 adult male albino rats of an average weight (150-180 gm) were obtained from Helwan breeding farm. They were housed and fed under the same environmental condition. These rats were divided into 4 groups:

The first group: (18 rats) was held as a control and received $1 \mathrm{~mL}$ physiological saline by a single intratracheal instillation.

The second group: (18 rats) was given $\left(\mathrm{CdCl}_{2}\right)$ in a dose of $40 \mu \mathrm{g} / \mathrm{kg}(1 / 2500$ of oral LD50) dissolved in 
physiological saline (Tátrai et al., 2001) ${ }^{\text {(a) }}$.

The third group: (18 rats) was given DDTC in a dose of $4 \mathrm{mg} / \mathrm{kg}(1 / 1000$ of oral LD50) dissolved in physiological saline (Tátrai et al., 2001) ${ }^{(\mathrm{a})}$.

The fourth group: (18 rats) was given both $\left(\mathrm{CdCl}_{2}\right)$ and DDTC together at the same dose for the second and third group.

The animals were given the above doses by single intratracheal instillation and put under observation. After 3 days, six rats of each group were anaesthesized with ether and blood was collected from retro-orbital venous sinus to measure the level of cadmium in blood, then the rats were killed, autopsied and the lungs were used in chemical detection of cadmium level at the above period. The rest of animals (12 in each group) were left and the same procedure was done after 7 and 21 days of exposure (according to Tàtrai et al., 2001). The lungs were examined histopathologically by light and electron microscope.

\section{Methods:}

I- Detection of the level of cadmium in blood and lungs:

The levels of cadmium in blood and tissues (lungs) were measured using the atomic absorption spectropho tometry. Tissue samples were prepared according to the method described by Al Ghias (1995).

Atomic absorption spectrophoto metery analysis techniques:

Filtered samples were analyzed for their cadmium content by using Unicam 969 Atomic absorption spectrometer in Toxicology Unit, Chemistry Department, Animal Health Research Institute - Cairo.

Instrumental analysis of cadmium was conducted by air/acetylene with flow rate of 0.9 to $1.2 \mathrm{~L} /$ minute lamp wave length 228.8 .

Quantitative concentration of cadmium in examined samples were calculated according to the following equation:

Concentration of cadmium metal in sample $(\mathrm{ppm})=\frac{A \times B}{W}$

Where:

ppm: means part per million

A: (concentration) ppm metal in prepared sample

B: final volume of prepared sample

W: weight of sample in gm.

\section{II - Histopathology:}

1- Light microscopy:

After 21 days of exposure to single intratracheal instillation of cadmium chloride and DDTC singly or in combination, the lungs were examined by light microscope. Lungs of control and treated animals were fixed in $10 \%$ phosphate buffered formalin. Section of 5 um thickness were stained with haematoxylin and eosin.

\section{2- Transmission Electron Microscopy} TEM

Lung biopsies, approximately $2 \mathrm{~mm}$ were fixed in $2.5 \%$ glutaraldehyde prior to processing for electron microscopic studies. Small specimens were post fixed in osmium tetroxide, dehydrated and embedded in Durcupan ACM fluka. Ultra-thin sections were cut, stained with uranyl acetate and lead citrate and studied with a Jeo JEM 100C transmission electron microscope.

\section{Results:}

I- Chemical detection to the level of cadmium in the blood and lung tissue:

Table (1) and Fig. (1) showed the level of cadmium in the blood after 3, 7 and 21 days of exposure in the groups that were treated with $\mathrm{CdCl}_{2}$, DDTC and 
combined $\left(\mathrm{CdCl}_{2}+\right.$ DDTC $)$. It was found that there was significant increase $(\mathrm{P}<0.001)$ in the level of cadmium with increasing the time in all groups but the level was slightly increased in the group received combined $\left(\mathrm{CdCl}_{2}+\right.$ DDTC).

Table (2) and Fig. (2) showed the cadmium concentration in the lung tissue of the treated animals after 3, 7 and 21 days of single intratracheal exposure. It was found that after 3 days, there was significant increase ( $\mathrm{P}$ $<0.001)$ in cadmium concentration in $\left(\mathrm{CdCl}_{2}\right)$ treated group and significant decrease $(\mathrm{P}<0.001)$ after combined exposure. While after 7 days all treated groups showed highly significant increase $(\mathrm{P}<0.001)$ in lung cadmium concentration, which decreased after 21 days.

\section{II- Histopathological Examin - ation}

\section{1- Haematoxylin and eosin stain:}

Light microscopic examinations of lung of control rats, showed no pathological changes. Examinations of the lung tissue of DDTC treated animals showed mild thickened alveolar septa with congestion and infiltration by inflammatory cells, specially around blood vessels (Fig. 3), while animals exposed to $\mathrm{CdCL}_{2}$ showed infiltration of alveolar septa by chronic inflammatory cells (lymphocytes and plasma cells) alveolar macrophages and fibroblasts (Fig. 4). On the other hand, lung tissue of animals treated by combined $\left(\mathrm{CdCL}_{2}+\right.$ DDTC) revealed more severe reactions. The alveolar septa were widened and infiltrated by chronic inflammatory cells with interstitial fibrosis. The alveolar spaces were narrowed and lined by cuboidal cells (Fig. 5).

\section{2- Transmission Electron Microscopy}

$\mathrm{E} M$ examination of lung tissue of rats treated by combined $\mathrm{CdCL}_{2}$ and DDTC showed damage of type I pneumocytes, hyperplasia of type II pneumocytes which replace type I. Lose of microvilli of type II cells. The interstitial tissue revealed collagen bundle and inflammatory cells (Fig. 6, 7).

Table (1): Cadmium concentration in the blood at different times after treatment with $\mathrm{CdCl}_{2}$, DDTC and combined treatment of $\left(\mathrm{CdCl}_{2}+\mathrm{DDTC}\right)$.

\begin{tabular}{||l|l|l|l|l||}
\hline \multirow{2}{*}{ Time } & \multicolumn{4}{|l||}{ Blood cadmium level ug/L (mean \pm SD) } \\
\cline { 2 - 5 } & CdCl 2 & DDTC & $\begin{array}{l}\mathbf{C d C l}_{2} \text { and } \\
\text { DDTC }\end{array}$ & Control \\
\hline \hline After 3 days & $\begin{array}{l}0.45 \pm 0.07 \\
\mathrm{P}<0.001\end{array}$ & $\begin{array}{l}0.34 \pm 0.09 \\
\mathrm{P}<0.05\end{array}$ & $\begin{array}{l}0.38 \pm 0.06 \\
\mathrm{P}<0.001\end{array}$ & $0.24 \pm 0.006$ \\
\hline After 7 days & $\begin{array}{l}0.78 \pm 0.11 \\
\mathrm{P}<0.001\end{array}$ & $\begin{array}{l}0.54 \pm 0.11 \\
\mathrm{P}<0.05\end{array}$ & $\begin{array}{l}0.55 \pm 0.06 \\
\mathrm{P}<0.001\end{array}$ & $0.24 \pm 0.01$ \\
\hline After 21 days & $\begin{array}{l}0.85 \pm 0.35 \\
\mathrm{P}<0.05\end{array}$ & $\begin{array}{l}0.82 \pm 0.14 \\
\mathrm{P}<0.05\end{array}$ & $\begin{array}{l}0.86 \pm 0.14 \\
\mathrm{P}<0.001\end{array}$ & $0.33 \pm 0.02$ \\
\hline
\end{tabular}

$P$ value less than 0.05 considered significant 
Table (2): Cadmium concentration in the lung at different times after treatment with $\mathrm{CdCl}_{2}$ DDTC and combined treatment of $\left(\mathrm{CdCl}_{2}+\mathrm{DDTC}\right)$.

\begin{tabular}{||l|l|l|l|l||}
\hline \multirow{2}{*}{ Time } & \multicolumn{4}{|l||}{ Cadmium level in lung u/g (mean \pm SD) } \\
\cline { 2 - 5 } & \hline $\mathbf{C d C l}_{\mathbf{2}}$ & $\mathbf{D D T C}$ & $\begin{array}{l}\mathbf{C d C l}_{\mathbf{2}} \text { and } \\
\text { DDTC }\end{array}$ & Control \\
\hline \hline After 3 days & $\begin{array}{l}8.3 \pm 0.05 \\
\mathrm{P}<0.001\end{array}$ & $\begin{array}{l}6.18 \pm 0.23 \\
\mathrm{P}<0.01\end{array}$ & $\begin{array}{l}2.05 \pm 0.008 \\
\mathrm{P}<0.001\end{array}$ & $4.81 \pm 0.05$ \\
\hline \multirow{2}{*}{ After 7 days } & $\begin{array}{l}8.59 \pm 0.004 \\
\mathrm{P}<0.001\end{array}$ & $\begin{array}{l}7.23 \pm 0.26 \\
\mathrm{P}<0.01\end{array}$ & $\begin{array}{l}7.56 \\
\pm 0.0006 \\
\mathrm{P}<0.001\end{array}$ & $4.77 \pm 0.08$ \\
\hline After 21 days & $\begin{array}{l}6.94 \pm 0.01 \\
\mathrm{P}<0.001\end{array}$ & $\begin{array}{l}4.41 \pm 0.17 \\
\mathrm{P}<0.05\end{array}$ & $\begin{array}{l}3.74 \pm 0.01 \\
\mathrm{P}<0.001\end{array}$ & $4.83 \pm 0.015$ \\
\hline
\end{tabular}

$P$ value less than 0.05 considered significant

Fig. (1): Cadmium concentration in the blood at different times after treatment with $\mathrm{CdCl2}$, DDTC and combined treatment of (CdCl2 + DDTC).

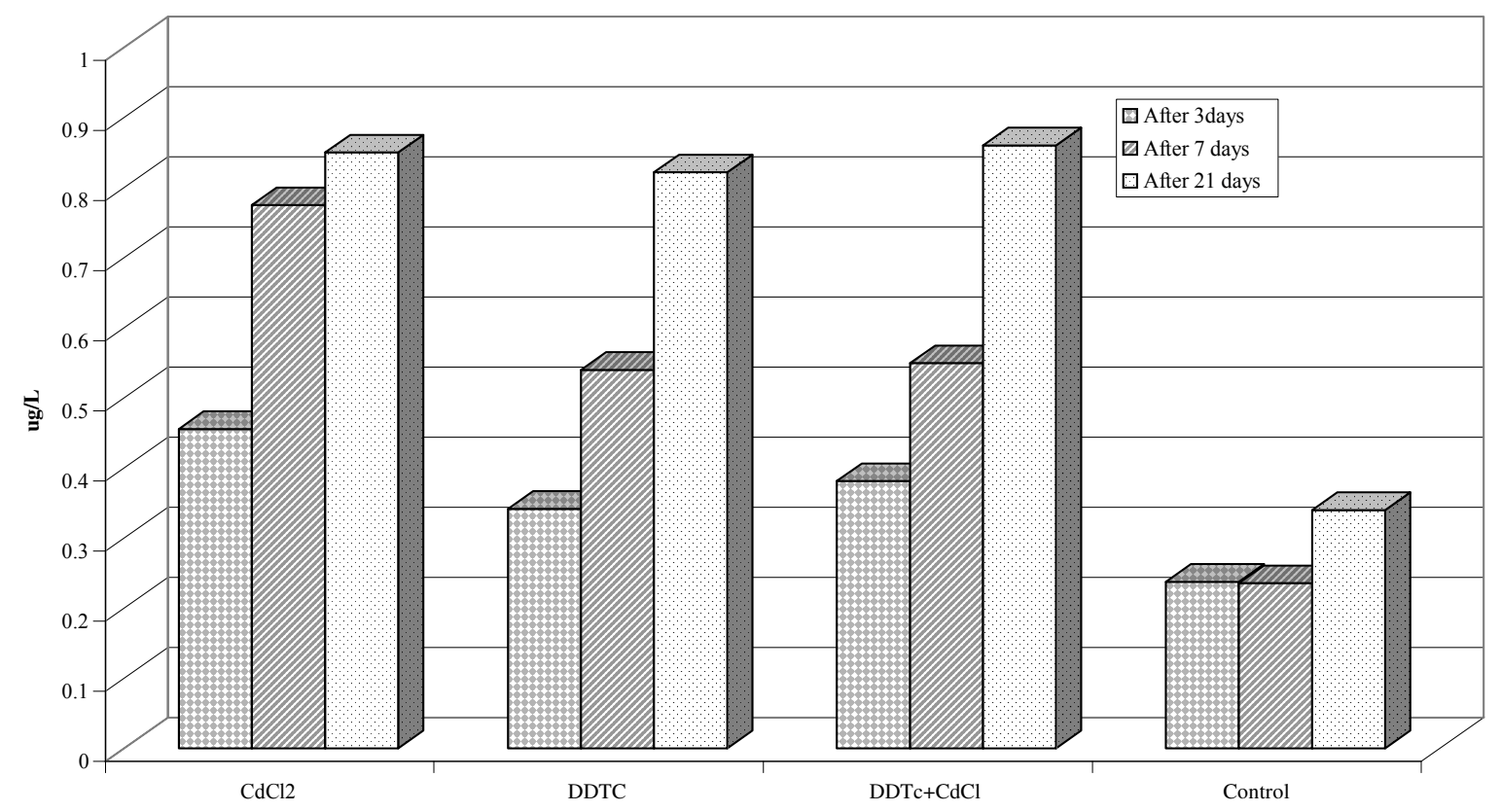


Fig. (2): Cadmium concentration in the lung at different times after treatment with $\mathrm{CdC}$, DDTC and combined treatment of CdCl2 + DDTC.
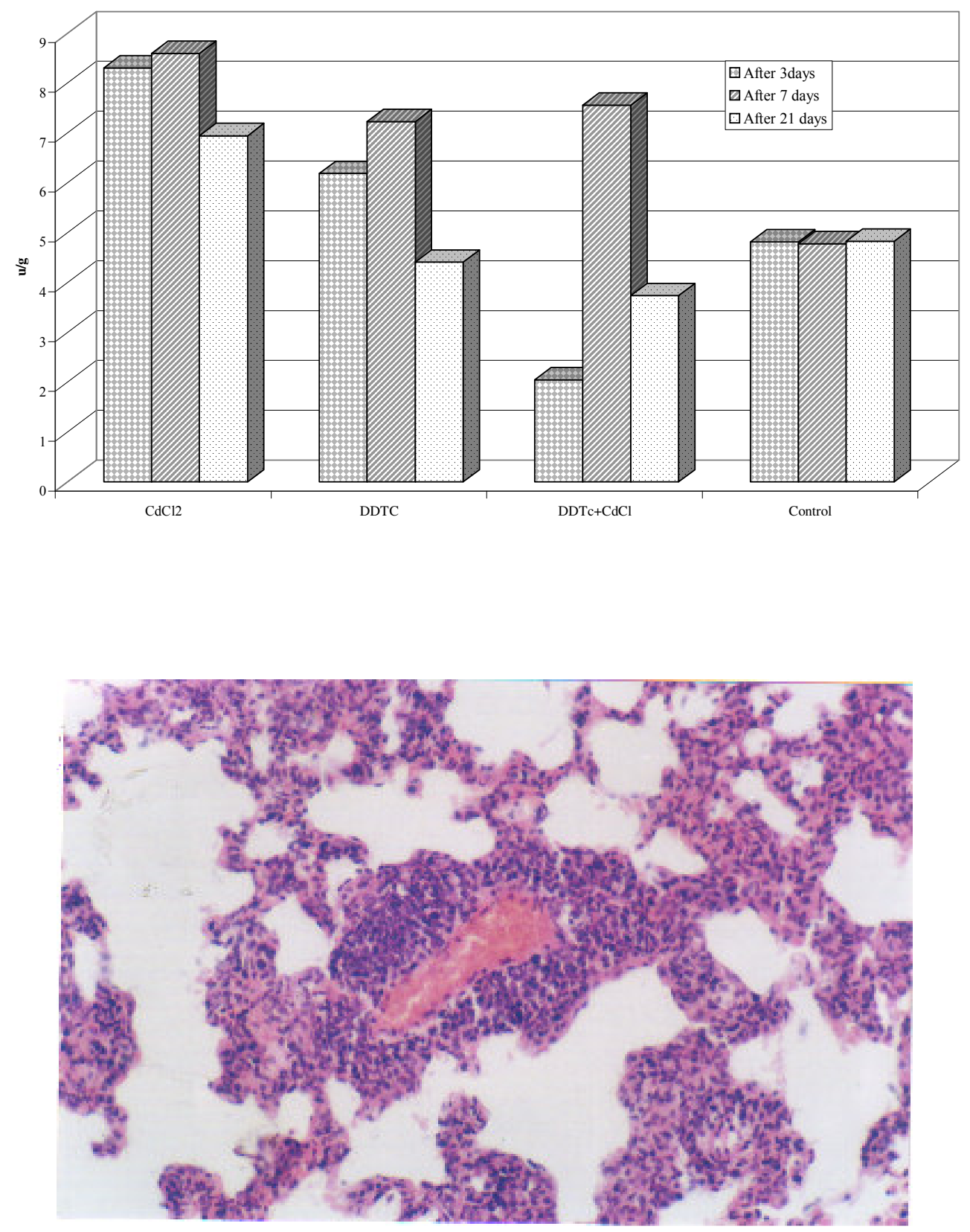

Fig. (3): A photomicrograph of section of rat lung treated with DDTC (after 21 days of single exposure), showing perivascular infiltration of the alveolar septa by lymphocytes and macrophages.

$(\mathrm{H} \& \mathrm{E} \mathrm{X} 400)$ 


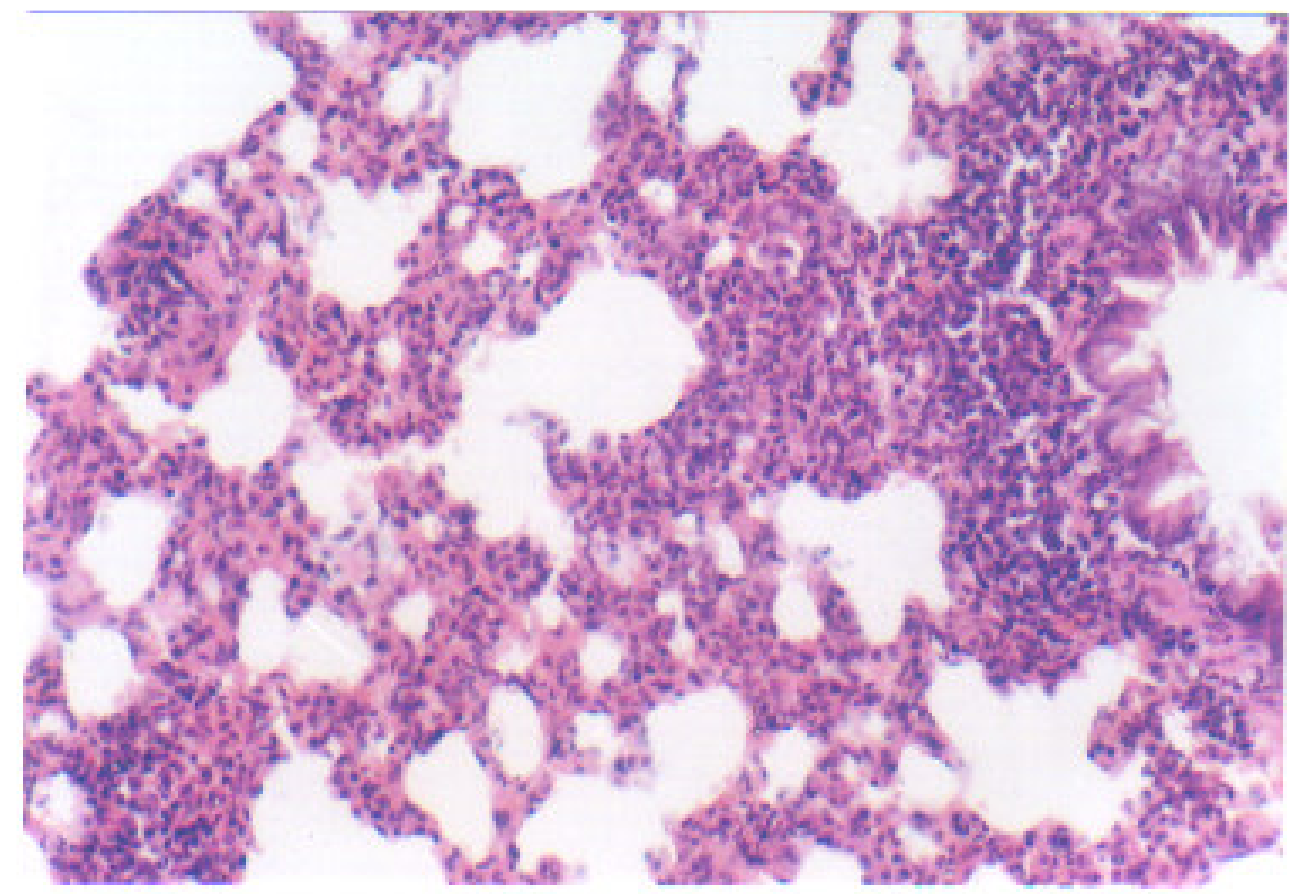

Fig. (4): A photomicrograph of rat lung section after 21 days of single exposure to $\mathrm{CdCL}_{2}$ showing widened alveolar septa with infiltration by chronic inflammatory cells, and interstitial fibrosis.

$(\mathrm{H} \& \mathrm{E} \mathrm{X} 400)$

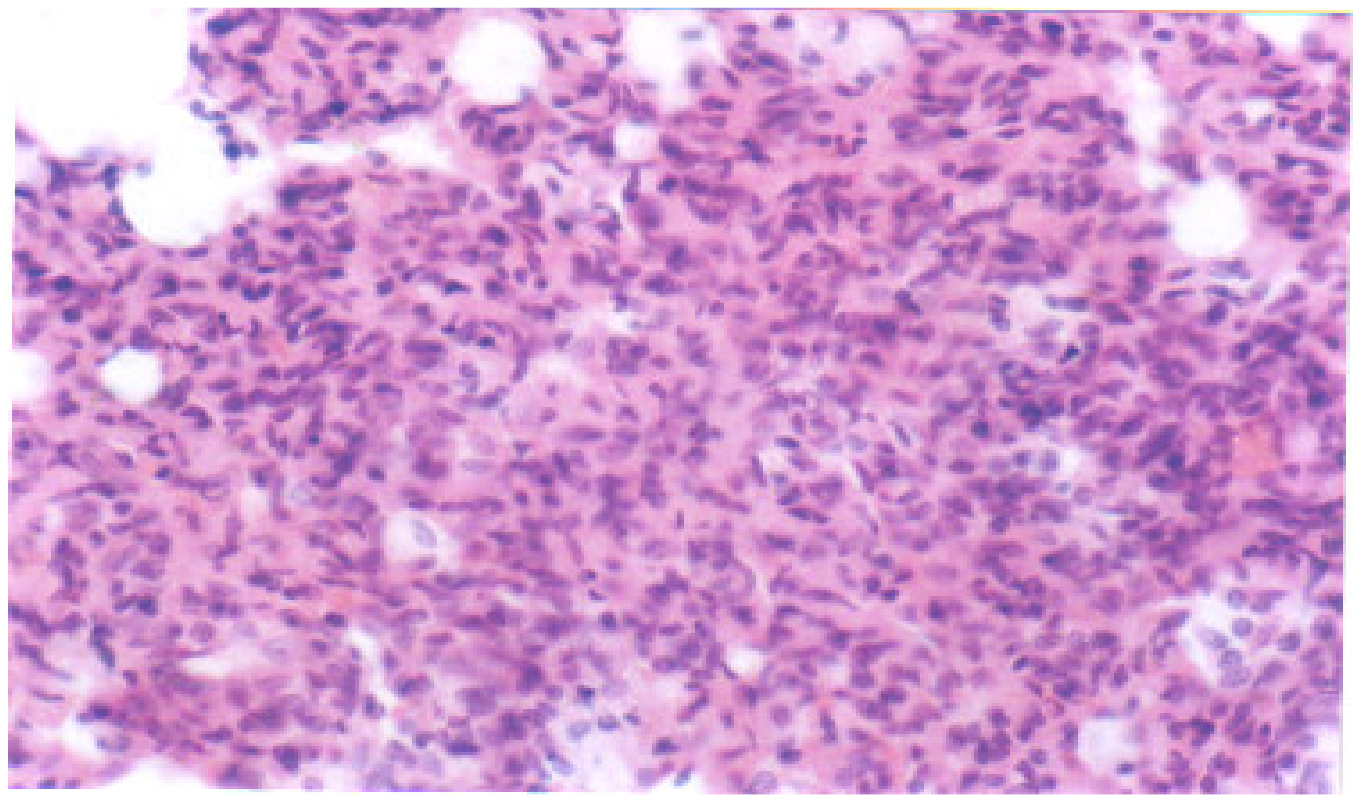

Fig. (5): A photomicrograph of rat lung section after 21 days of combined exposure showing thickened alveolar septa, marked interstitial fibrosis, chronic inflammation and narrowed spaces lined by cuboidal type II epithelial cells.

(H\&E X 650) 


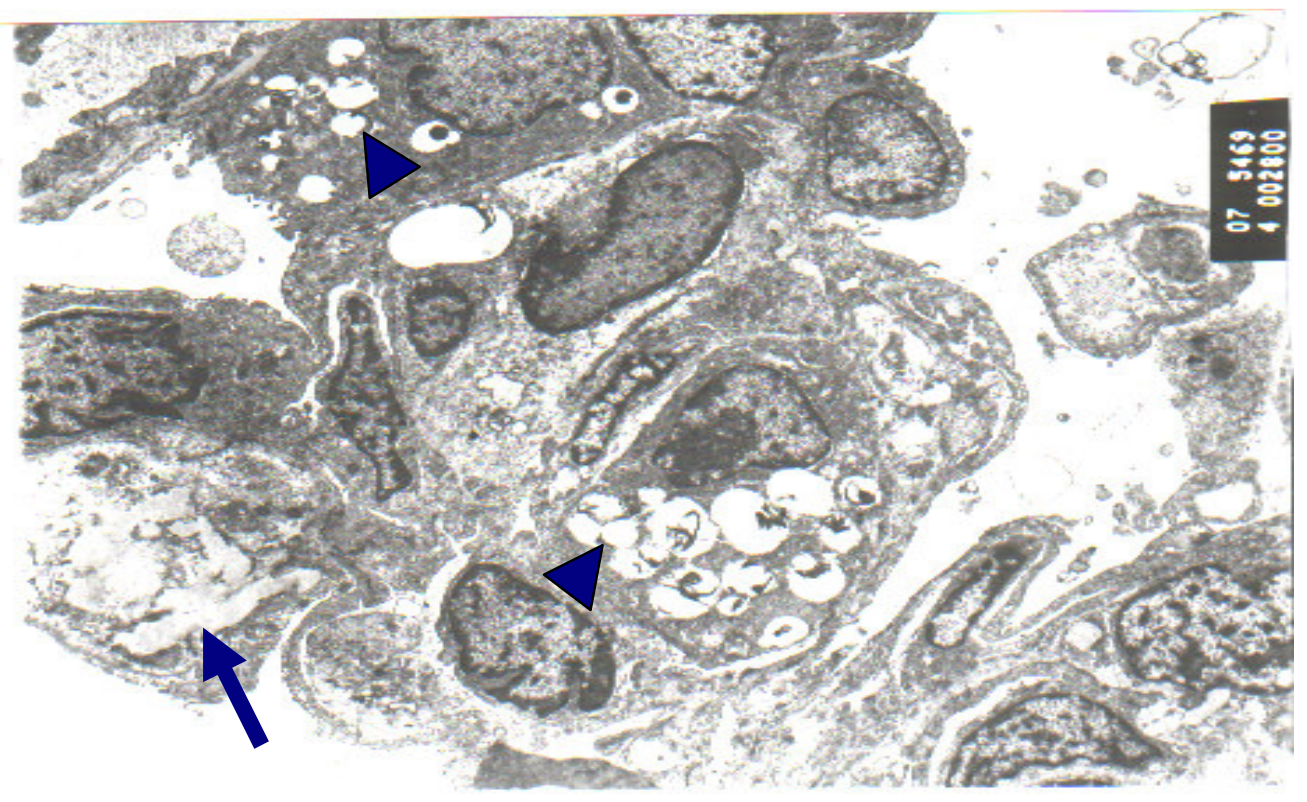

Fig. (6): Rat lung after 21 days of treatment with DDTC and $\mathrm{CdCL}_{2}$ in TEM, Hypertrophic type II pneumocytes (arrow head) replace type I pneumocytes, most of their micro villi disappear. Collagen deposits and macrophages accumulate in the interstitium (arrow).

(X2800)

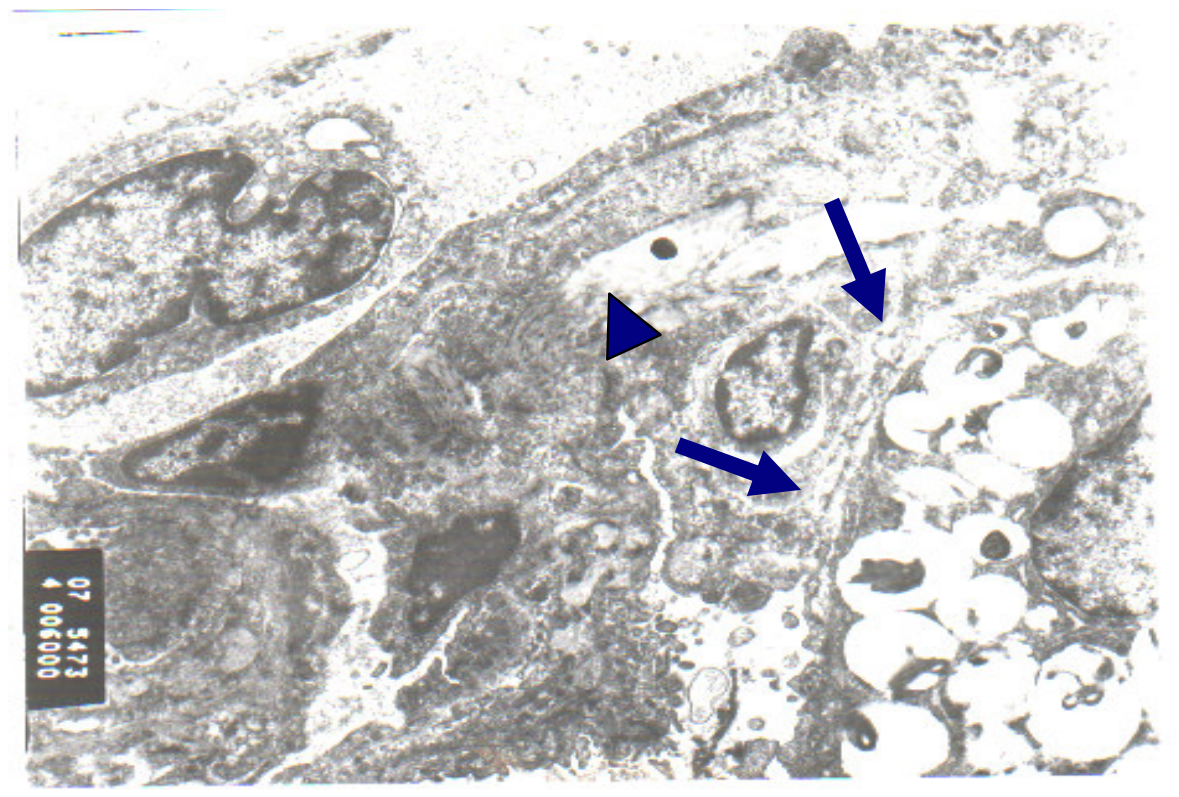

Fig. (7): Higher magnification showing types II pneumocytes with their laminar bodies (arrow) and collagen bundle in the interstitial tissue (arrow head). 


\section{Discussion:}

Cadmium and carbamates are two contaminants of our environment. In this work the pulmonary toxicity of cadmium chloride $\left(\mathrm{CdCl}_{2}\right)$ and sodium diethyldithiocarbamate (DDTC) each separately and in combination was studied. This study included the chemical and morphological methods. As regards the chemical method, it was found that cadmium content of the serum of $\left(\mathrm{CdCl}_{2}\right)$ treated group animals and of combined treated group was significantly increased $(\mathrm{P}<0.001)$ with increasing the time after single exposure with highest level in combined treated group after 21 days of exposure. This result is in agreement with that was reported by Klaassen, (1985) that cadmium most prone to accumulate in the body. Its level increases throughout life as its biological half life is 10-30 years. In our study the cadmium concentration of the lung tissues, in the control group had a mean level of 4.81 $\pm 0.05 \mu \mathrm{g} / \mathrm{g}$. While in cadmium treated group the mean level was $8.3 \pm 0.05$, $8.59 \pm 0.004$ and $6.944 \pm 0.01 \mu \mathrm{g} / \mathrm{g}$ at 3 , 7, 21 days respectively. Rahola et al., (1972) reported that most of cadmium accumulates from contaminated food, water and inhalation of airborn cadmium including cigarette smoking (Scand, 1986). This may explain the presence of cadmium in control lung and blood, in addition to its long half life. In our work the combined group showed significant increase $(\mathrm{P}<0.001)$ in cadmium concentration of the lung tissues after one week compared to significant decrease $(\mathrm{P}<0.001)$ after 3 days. This is in agreement with Tàtrai et al., $\left(2001^{(\mathrm{a})}\right)$ who found that although dithiocarbamates as chelating agents are suitable for the removal of cadmium from organisms, they alter the redistribution of cadmium within the organism, thereby increasing the cadmium content in the lungs. In this work the significant decrease in the cadmium concentration in the combined group after 3 days may be explained by that was reported by Tandon et al., (1998) that the chelating agents, at least partly, transport cadmium from the liver and possibly from other sites into the kidney.

As inhalation of cadmium produces the greatest toxic hazard (Tibbits and Milroy, 1980), death is usually attributed to severe pulmonary oedema (Taylor et al., 1984). So, in our study we investigated the lung histopathologically after single intratracheal exposure. It was found that DDTC treated animals showed inflammatory infiltrate around interstitial blood vessels and mild fibrosing alveolitis. This finding were similar to that reported by Tàtrai et al., (1998). In $\mathrm{Cd} \mathrm{Cl}_{2}$ treated group there were interstitial fibrosis, chronic inflammation and injury of type I pneumocytes, hyperplasia of type II pneumocytes with loss of their microvilli. These results were consistent with that obtained by Tàtrai et al., $\left(2001^{(\mathrm{b})}\right)$.

Driscol and Miller, (1992) concluded that pulmonary fibrosis produced by $\left(\mathrm{CdCl}_{2}\right)$ was due to stimulation of alveolar macrophages fibronectin and this fibrosis occurred at all $\left(\mathrm{CdCl}_{2}\right)$ levels. While Lin et al., (1992) found that the histopathological changes increased with increasing the time of exposure (dose dependent). In our study the morphological examination of lung tissues showed extensive and more serious lesions in combined exposure than in the case of $\left(\mathrm{CdCl}_{2}\right)$ or DDTC alone, owing to the formation of DDTC - cadmium 
lipophilic chelate complex. This result was in consistent with the result that was obtained by Tàtrai et al., $\left(2001^{(\mathrm{a})}\right)$ who concluded that combined treatment led to a redistribution of cadmium ions. Further-more, the pathological alterations of the alveolar epithelium may have an important role in the initiation and maintenance of the inflammatory processes in the lung. Smith et al., (1995) reported that alveolar epithelial cells may control the local concentration and state of activation of alveolar macrophages and thus contribute to the initiation or maintenance of beneficial or harmful inflammatory process within the lung. An important mechanism by which alveolar epithelial cells might regulate the inflammatory milieu of the alveolar space takes place through the production of cytokines (Kovacs and Dipietro, 1994) which are chemotactic for and activate monocytes or alveolar macrophage (Brieland et al., 1995).

In our study the combined treatment animals showed pulmonary fibrosis and hyperplasia of type II pneumocytes with loss of their microvilli. Recently there has been an increasing awareness that pulmonary type II alveolar epithelial cells are very important for maintaining the structural and functional integrity of the lung (Rodriguez et al., 1987).

The extensive changes developed in the Lung upon the effect of Combined expasure could be attributed to the fact that all chemicals in a given mixture act in the same way - by the same mechanism - and differ only in their potencies (Mumtaz et al., 1998).

Conclusion and Recommendation:

Cadmium is one of the heavy metals which has greatest toxicologic concern. The combined exposure to cadmium and thiocarbamate showed extensive and serious pulmonary changes. So, the possible interaction between environmental agents must receive considerable attention.

\section{References:}

1- Al-Ghais, SM (1995): Heavy metal concentrations in the tissues of sparns Serba from the united Arab Emirates. Bull, Environ. Contam. Toxicol.; 55:581.

2- Bell RR, Soliman MR, Nonavinakere and Hammerbeck DM (1997): Cadmium and/or Selenium effects on guinea pig lung $\mathrm{PGE}_{2}, \mathrm{TXB}_{2}$ and $\mathrm{LTC}_{4}$. Res. Commun. Mol. Pathol. Pharmacol.; 97(2): 233-6.

3- Brieland JK, Flory CM, Jones ML, et al., (1995): Regulation of monocyte chemoattractant protein-1 gene expression and secretion in rat pulmonary alveolar macrophages by lipopolysaccaride tumor necrosis factor and interleukin. Am. J. Respir. Cell. Mol. Biol.; 12: 104-109.

4- Driscoll $J$ and Miller NS (1992): Stimulation of rat alveolar macrophage fibronectin release in a cadmium chloride model of lung injury and fibrosis. J. Toxicol. Environ. Health; 35(1): 63-76.

5- $\quad$ Fogu G, Congiu AM, Campus $P M$ and Ladu $R$ (2000): Genotoxic effects of cadmium chloride on human amniotic fluid cells cultured in vitro. Ann. Chim.; 90(11-12): 709-14.

6- Gale GR, Walker Jr and Smith $A B$ (1983): Effects of combined treatment with diethyl dithiocarbamate and dihydroxyethyl dithiocarbamate on distribution and excretion of cadmium. Resp. Commun. Chem. Pathol. Pharmacol.; 41: 293-302.

7- $\quad$ Gossel T and Bricker J (1994): Metals In: Principles of clinical toxicology, Raven Press, New York, Third edition; pp. 186-187.

8- $\quad$ Habeebu SS, Liu J, Liu Y and Klaassen CD (2000): Metallothionein null mice are more susceptible than 
wild-type mice to chronic $\mathrm{CdCl}^{2}$ induced bone injury. Toxicol. Sci.; 56(1): 211-9.

9- Hovland DN, Machado AF, Scott WJ and Collins MD (1999): Differential sensitivity of the SWV and GS $7 \mathrm{BL} / 6$ mouse strains to the teratogenic action of single adminis tration of cadmium given throughout the period of anterior neuropore closure. Teratology; 60(1): 13-21.

10- Karmakar $R, \quad R o y \quad S$ and Chatterjee MC (1999): The effects of cadmium on the hepatic and renal levels of reduced glutathione, the activity of glutathion S-transferase and gamma glutamyl transpeptidase. J. Environ. Pathol. Toxicol. Oncol.; 18(1): 29-35.

11- Keshava N, Zhou G, Hubbs AF, Ensell MX and Ong TM (2000): Transforming and carcinogenic poten tial of cadmium chloride in BAL B/C313 cells. Mutat Res.; 448(1): 23-8.

12- Klaassen CD (1985): Heavy metals and heavy metal antagonists. In: Gilman AG, Goodman LS, Rall TW, Murad F. eds. The pharmacological basis of therapeutics. $7^{\text {th }}$ ed. New York; MacMillan; 1985: 1605-1627.

13- Kovacs EJ and Dipietro LA (1994): Fibrogenic cytokines and connective tissue production. FASEB. J.; 8: 854-861.

14- Lin CJ, Yang PC, Hsu MT, Yew FH, Liu TY et al., (1992): Induction of pulmonary fibrosis in organ cultured rat lung by cadmium chloride and transforming growth factor Toxicol. Appl. Pharmacol.; 116(1): 307.

15- Liu, J; Liu, Y; Habeebu SS and Klaassen CD (1999): Metallothionein null mice are highly susceptible to the hematotoxic and immunotoxic effects of chronic $\left(\mathrm{CdCl}_{2}\right)$ exposure. J Toxicology and Applied Pharmacology; 159(2): 98108.
16- Martin JJ, Martin R, Codesal J and Fraile $B$ (2001): cadmium chloride - induced dysplastic changes in the ventral rat prostate: an immunohistochemical and quantitative study. Prostate; 46(1): 11-20.

17- $\quad$ Marth E, Barth $S$ and Jelovcan $S$ (2000): Influence of cadmium on the immune system. Description of stimulating reactions. Cent. Eur. J. Public Health; 8(1): 40-4.

18- Mumtaz MM, De Rosa CT, Groten J, Feron VJ, Hansen $H$ and Durkin PR (1998): Estimation of toxicity of chemical mixtures through modeling of chemical interactions. Environ Health Perspect; 106 Suppll.; 6: 1333-60.

19- Novelli EL, Vieira EP, Rodrigues $N L$ and Ribas BO (1998): Risk assessment of cadmium toxicity on hepatic and renal tissues of rats. Environmental Research; 79(2): 102-5.

20- Rahola T, Aaran RK, Mietinen JK (1972): Half time studies of mercury and cadmium by whole body counting. In: Assessment of radioactive contam ination in man. Vienna; International Atomic Energy Agency; 1-25.

21- Rodriguez MS, Bur A, Favre A and Weibel ER (1987): The pulmonary acinus geometry and morphometry of the peripheral air way system in rat and rabbit. Am. J. Anat.; 180: 143-155.

22- Scand J (1986): Air born cadmium and carcinogenesis of the respiratory tract. J. Work Environ. Health; 12(6): 523-37.

23- $\quad$ Smith RE, Strieter RM, Zhang $K$, Phan SH (1995): A role of C-C chemokines in fibrotic lung disease. J. Lenkocyte Biol.; 57: 782-787.

24- Tandon SK, Prasad S, Singh Sad Agarwal DK. (1998): Efficacy of amphipathic dithiocarbamates in intracellular cadmium mobilization and in modulation of hepatic and renal 
metallothionein in cadmium preexposed rat. Chem. Biol. Interact.; 114(3): 161-75.

25- Tàtrai E, Nàray $M$, Brózik $M$, Adamis $Z$, Ungvàry $G$ (1998): Combined pulmonary toxicity of dieth yldithiocarbamate and lead (II) oxide in rats. J. Appl. Toxicol.; 18:33-37.

26- Tàtrai E, Bròzik M, Nàray M, Adamis $Z$ and Ungvary $G(2001)^{(a)}$ : Combined pulmonary toxicity of cadmium chloride and sodium diethyldithiocarbamate. Journal of Applied Toxicology; 21:101-105.

27- Tàtrai E, Kovàcikova Z, Hudàk A, Adamis $Z$ and Ungvàry $G(2001)^{(b)}$ :

Comparative in Vitro toxicity of cadmium and lead on redox cycling in type II pneumocytes. J. Appl. Toxicol.; 21: 479-483.

28- Taylor A, Fackson MA, Patol D et al., (1984): Poisoning with cadmium fumes after smelting lead. Br. Med. J.; 288: 1270-1271.
29- Tibbits PA and Milroy WC (1980): Pulmonary edema induced by exposure to cadmium oxide fume: case report. Milit. Med.; 145: 435-437.

30- Tinkler J, Gott D and Bootman $J$ (1998): Risk assessment of dithiocarbamate accelerators residues in latex-based medical devices: genotoxicity consideration. Food Chem. Toxicol.; 36 (9-10): 849-66.

31- Wang $R$, Wang XT, Wal and Metaasen MA (1999): $\quad$ Toxic

effects of cadmium and copper on the isolated heart of dogfish shark. Squalus Acanthias. J. Toxicol. Environ. Health A. 57(7): 507-19.

32- Williams DR and Halsted BW (1982): Chelating agents in medicine. J Toxicol. Clin. Toxicol.; 19:1081-1115. 33- World Health Organization (WHO) (1988): Environmental Health Criteria 78. Dithiocarbamate pesticides, ethylenethiourea and propylenethiourea: A General Introduction. WHO: Geneva, 15. 


\section{دراسة هستوباثولو جية و كيميائية عن التسمم الرئوى الناتج من التعرض لمادتى كلوريد الكادميوم والثايو كارباميت}

\section{سمية يوسف مصطفى حمودة، سامية إبراهيم النجار و هانى حلمى حليم}

من أقسام الطب الشرعى والسموم كلية طب بنات الأزهر والباثولوجى بكلية الطب جامعة القاهرة وقسم

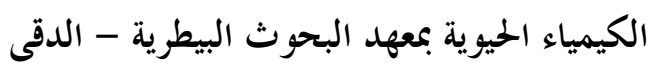

يهلدف هذا البحث لدراسة التسمم الرئوى الحلاد لمادتى كلوريد الكادميوم والثايو كارباميت عند التعسرض

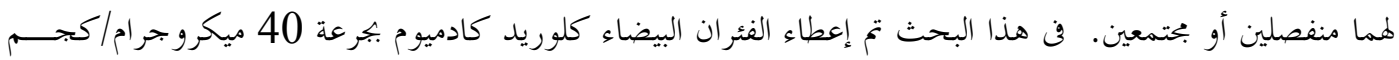

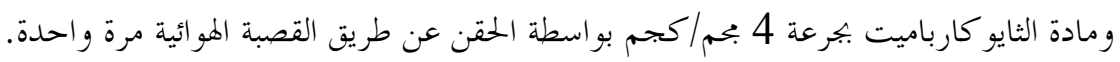

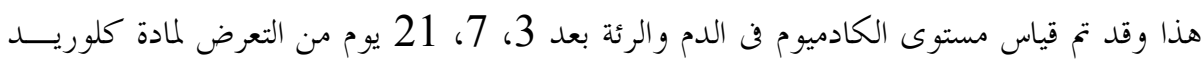
الكادميو فقط والتعرض للمادتين معاً.

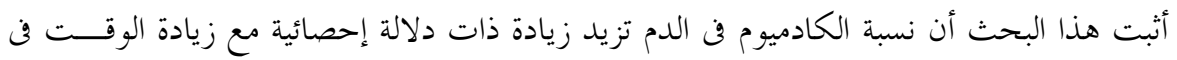

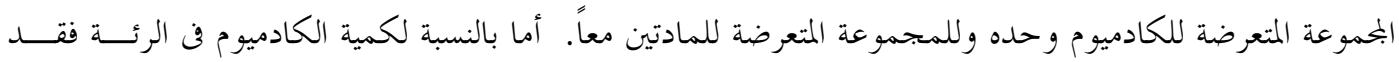

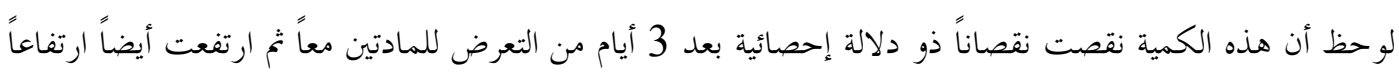

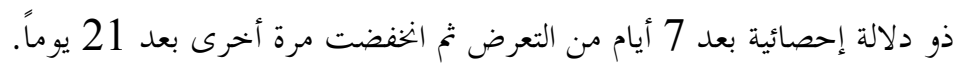

وعند فحص الرئة بواسطة الميكروسكوب الضوئى لوحظ وجود ارتشاح حاد فن فواصل الحويصلات الموائية

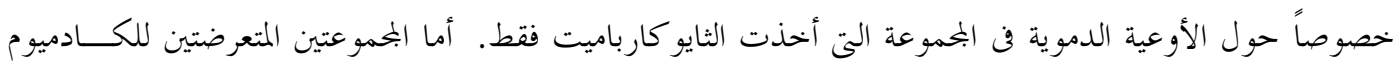

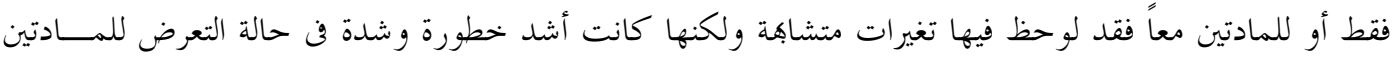

أما الفحص بواسطة الميكروسكو ب الإلكتروفن فقد أثبت تدمير للخلايا الرئوية (نيمو سايت النسـوع الأول)

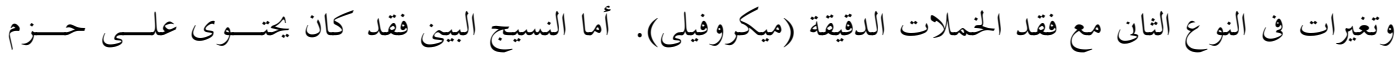
كولاجينية وخلايا التهابية. 